\title{
Why "Austerity" Failed in Greece: Testing the Validity of Macro-Economic Models
}

\author{
Frederick Betz' ${ }^{1}$ Elias Carayannis ${ }^{2}$ \\ ${ }^{1}$ Portland State University and SUNY Korea, Songdo, Republic of Korea \\ ${ }^{2}$ George Washington University, Washington DC, USA \\ Email: fbetz@venture2reality.com
}

Received 6 May 2015; accepted 9 June 2015; published 15 June 2015

Copyright (C) 2015 by authors and Scientific Research Publishing Inc.

This work is licensed under the Creative Commons Attribution International License (CC BY). http://creativecommons.org/licenses/by/4.0/

(c) () Open Access

\begin{abstract}
During the Euro Crisis which began in 2009 and is still continuing in 2015, Greece provided an interesting case of an empirical test of some macro-economic theories-particularly the theory underpinning the European Union (EU) policy of "austerity". Fiscal austerity had been imposed upon the Greek governments as the price of EU bailout of bankrupt Greece. But after five years, the EU austerity policy was judged by many as a failure, and Greece continued to struggle at the bottom of a depression. Underlying the austerity policies, there was a macro-economic model called the Polak model. We examine whether or not this model was valid in the Greek economic context. Identifying the conceptual model underlying economic policy is important to clarify the validity or the invalidity of the model assumptions upon which a policy rests. We compare the macro-economic Polak model to an alternative model of the Greek fiscal crisis as "disequilibrium-pricing" in financial markets. An empirically invalid model can suggest bad policy, which may not solve an economic problem but can even deepen a crisis. An empirically valid model can provide a realistic basis for formulating effective policy.
\end{abstract}

\section{Keywords}

Fiscal Models, Macro-Fiscal Policy, Economics, Financial Systems

\section{Introduction}

Since the fiscal crises of the US in 2008 and the European Euro-dollar crisis from 2009, much attention is being paid to "fiscal policy" and macro-economic models underlying policy. There are many widely respected economists who have written about this. Nouriel Roubini emphasized that several economic questions need to be restudied. These include the appropriate relation of public debt to economic growth, the causes of large continuous 
debts in government budgets, and how large government debt can be reduced without throwing a nation into depression. Also Roubini cautioned about a policy of "austerity" to quickly reduce debt (front-loading) by immediately and simultaneously increasing taxes and reducing government employment and pensions [1]. Paul Krugman wrote that the Greek fiscal crisis came as a shock to European Union officials, as previous Greek Governments had falsified debt information: "As the news sank in with investors, first Greece, then much of Europe, found itself in a new kind of crisis - one not of failing banks but of failing governments, unable to borrow on world markets [2]." Such consequences did occur in Greece and other EU countries, which had the "front-loaded" EU austerity policy applied to them in exchange for EU bail-out assistance.

In Greece, even by 2015, the empirical result was that Greece had not grown out of a depression during four years of the austerity program. Describing this, Mark Blyth wrote: "In line with such (austerity) thinking, and following the shock of the recent financial crisis, which caused public debt to balloon, much of Europe has been pursuing austerity consistently for the past four years. The results of the experiment are now in, and they are equally consistent: austerity doesn't work. Most of the economies on the periphery of the Eurozone have been in free fall since 2009, and in the fourth quarter of 2012, the Eurozone as a whole contracted for the first time ever. Portugal's economy shrank by 1.8 percent, Italy's fell by 0.9 percent, and even the supposed powerhouse of the region, Germany, saw its economy contract by 0.6 percent. The United Kingdom, despite not being in the Eurozone, only barely escaped having the developed world's first-ever triple-dip recession [3].” This report emphasized that the front-loaded austerity policy had only triggered recessions, without immediate relief of debt.

Dealing with the Euro-dollar crisis, the International Monetary Fund (IMF) was one of the three (troika) of financial institutions, which included the World Bank and EU Central Bank. In the past (particularly during the Asian Financial Crisis of 1998), the IMF had used a macro-economic model, the Polak model, upon which to base its programs of austerity. Yet in the earlier Asian Financial Crisis, the IMF experienced that a "front-loaded" austerity policy (raising taxes while simultaneously reducing government spending) had pitched some IMFaided countries deeper into a fiscal crisis which turned into severe economic recessions. As one of the "EU troika" later in July 2012, the IMF even cautioned about possible undesirable consequences of "austerity".

Some form of economic model, perhaps similar to the Polak model, underlay economic thinking by EU economists in 2009-2015. This is evidenced by the EU emphasis, all during this crisis, upon the "productivity" in the affected nations. EU economists emphasized the importance of the "cost-of-labor" as a major factor in "economic competitiveness" and this appeared in the EU publication in 2011, entitled: "Conclusions of The Heads of State or Government of The Euro Area" (Brussels, March 11, 2011). Under the topic of Foster Competitiveness, the document stated: "Progress will be assessed on the basis of wage and productivity developments and competitiveness adjustment needs. To assess whether wages are evolving in line with productivity, unit labor costs (ULC) will be monitored over a period of time, by comparing with developments in other Euro area countries and in the main comparable trading partners. For each country, ULCs will be assessed for the economy as a whole and for each major sector (manufacturing; services; as well as tradable and non-tradable sectors). Large and sustained increases (in labor wages) may lead to the erosion of competitiveness, especially if combined with a widening current account deficit and declining market shares for exports [4]." One sees in this prescription of the EU commission that there was an assumption that increasing "labor wages" lowers a "national productivity".

Economically, "productivity" is judged as "good" because it leads to higher exports by a nation (more competitiveness); and the Polak model was constructed explicitly upon a difference between exports and imports of a nation. But this is not an obvious assumption. In management theory, an increase in labor wages decreases business profitability but not necessarily business productivity. Automation is a more important factor in increasing productivity because it multiples labor productivity. This economic concept of "wages" as directly coupled to "productivity" is at odds with the management concept of "automation" as being more directly coupled to "productivity".

Testing a social science theory for empirical validity (such as the macro-economic theory underlying "austerity"), one needs first to methodologically formulate a specific "model" within the principles of the theory-in order to test the validity of the model in the empirical context of a historical event of a society. Models can be directly empirically verified or invalidated. Theory and theoretical principles of a theory are only indirectly validated/invalidated by implications of the validity of their models. In this research, we compare the Polak model to an alternative macro-economic fiscal model based upon the theory of disequilibrium-pricing and systemsdynamics modeling techniques. We examine the validity of each model in the empirical case of Greece-in or- 
der to understand why austerity failed.

This is a contemporary case study; and in the style of case studies, extensive direct quotes are used to provide references to sources of historical evidence. Contemporary cases are a blend of the case approach and historical methodology. In historical methodology, sources and direct quotes provide evidence of historical information and interpretation. Contemporary case studies derive historical information from investigative reporters on economic and financial events and on interpretation of these events by contemporary economists and economic commentators. The direct quotes in this article point to sources of historical evidence on the Greek fiscal event and interpretations of it. Case studies in economics can be used to provide a basic empirical technique in institutional and micro-economic analyses of the validity of theory and models.

\section{Austerity Program and IMF Macro-Fiscal Model-Polak Model}

The Polak model had long been used by the IMF in justifying its policy of austerity in assisting an economically troubled nation. Ngaire Woods explained: “Crucially, the Polak model linked a country's domestic economic policies to its balance of payments position. This opened the door for IMF conditionality (conditions for making an IMF loan to a country)... The starting point of the Polak model is what was known (in macro-economic theory) as the 'absorption approach' to the balance of payments - that a country with a balance of payments deficit was absorbing too many resources in consumption and investment, relative to what that country can produce. With a couple of simplifying assumptions, it will follow that a country which increases domestic credit too rapidly will encounter increasing balance of payments deficits reflected in a loss in central bank reserves... On the basis of this analysis, when a country has a balance of payments deficit, the Fund's prescription focuses on reducing government spending, increasing taxes, and reducing domestic credit creation [5].”

In 1989 and 1998, J. J. Polak had published his model, and his paper was reprinted later as collected essays [6]. The Polak Model consisted of four equations:

(1) $\mathbf{I}=\mathbf{k} \mathbf{P}$

Imports $(\mathbf{I})$ are proportional $(\mathbf{k})$ to GDP $(\mathbf{P})$.

(2) $\mathbf{E}-\mathbf{I}=(\mathbf{\Delta R}-\mathbf{C})$

Exports $(\mathbf{E})$ minus Imports $(\mathbf{I})$ are equal to (Change-in-Reserves $(\mathbf{A R})$ minus Net-Capital-Inflow $(\mathbf{C})$ of the non-banking sector).

(3) $\Delta \mathbf{M}=\mathbf{k} \Delta \mathbf{P}$

Change-in-Money-Supply $(\mathbf{\Delta M})$ is proportional $(\mathbf{k})$ to Change-in-Gross-Domestic-Product $(\boldsymbol{\Delta P})$.

(4) $\Delta \mathbf{R}=(\Delta \mathbf{M}-\Delta \mathbf{D})$

Change-in-Reserves $(\boldsymbol{\Delta R})$ equals (Change-in-Money-Supply $(\boldsymbol{\Delta} \mathbf{M})$ minus Change-in-Domestic-Credit $(\boldsymbol{\Delta D})$.

The first equation is about imports (I) and exports (E) in a nation, asserting that: Imports $(I)$ are proportional to the total revenue $(P)$ in a nation. In the case of Greece, this was a questionable assumption. In any nation, what-is-imported and what-is-exported depends upon what-cannot-be-produced-in-a-nation (Imports) and what-can-be-produced (Exports). But what-can-be-produced and what-needs-to-be-imported bears no relation to the total revenue. Instead, what-can-be-produced depends upon the industrial technology in a nation and the resources of a nation. For example by 2009, Greece did not produce automobiles, and many Mercedes and other automobiles manufactured in Germany were purchased by Greek citizens, under the low interest rates available then in Euro dollar countries. The import of German cars into Greece had less to do with GDP than with interest rates on car loans (with low rates due to Greece's participation in the Eurodollar). One of Greece's primary "exports" then lay in the "import" of tourists (a service industry rather than a manufacturing industry). Greece received German and other European tourists, enjoying the climate and beauties of the Aegean Sea, with tourism contributing at least $18 \%$ to GDP.

Thus for Greece, the first equation (I = kP) was not true. Imports (I) in Greece were not at that time directly related to the Gross Domestic Product (P). The level of imports was financed not by the level of GDP but by the availability of inexpensive foreign credit. It was excessive borrowing of money (foreign loans) which increased the level of national imports, far more than did their GDP. Polak's first macro-economic assumption about imports and GDP was not historically correct in Greece in the Euro crisis.

The second equation was about imports (I) and exports (E) in a nation: $\mathbf{E}-\mathbf{I}=(\Delta \mathbf{R}-\mathbf{C})$. It assumed that the difference between Exports (E) and Imports (I) depended upon changes-in-money-reserves $(\Delta R)$ in the central bank of the nation and upon the inflow of capital (C) into the non-banking sectors. Did exports increase over 
imports when the central bank reserve of money increased in Greece? No. Imports were principally dependent upon the international financial community buying Greek sovereign bonds, which subsidized government employment. The difference of exports-to-imports bore little relation to the amount of gold held by the Greek central bank, instead reflecting the sales of Greek sovereign bonds.

Also the second equation ( $\mathbf{E}-\mathbf{I}=\boldsymbol{\Delta} \mathbf{R}-\mathbf{C}$ ) assumed that the difference between Exports (E) and Imports (I) depended negatively upon the inflow of capital (C) into the non-banking sectors. This meant if companies in the nation borrow less in foreign loans, then exports will increase over imports. Certainly financial strength in a nation could increase exports-but only if financial strength is used to invest in more manufacturing capability in the nation. Thus Polak's second macro-economic assumption is contextually dependent on how a country uses its wealth, upon its micro-economic structure. In Greece, the inflow of capital (C) did not finance manufacturing development but financed government employment. The difference of exports and imports had no direct relationship to decrease in foreign loans. This macro-economic assumption was not historically true in Greece.

For the third equation $\mathbf{\Delta M}=\mathbf{k} \mathbf{\Delta} \mathbf{P}$, the assumption was that Change-in-Money-Supply $(\boldsymbol{\Delta M})$ is proportional $(\mathbf{k})$ to Change-in-Gross-Domestic-Product $(\boldsymbol{\Delta} \mathbf{P})$. In Greece, this also was not true. As a member of the EU Euro dollar currency, Greece had no control over its currency. It could not inflate its supply of money to lower the costs of servicing national debt. Polak's third equation was not true in Greece, in the times leading up to and during its fiscal crisis.

For the fourth equation ( $\Delta \mathbf{R}=\Delta \mathbf{M}-\Delta \mathbf{D})$, the Change-Reserves $(\boldsymbol{\Delta R})$ did not in Greece actually equal the Change-in-Money-Supply $(\mathbf{A M})$ minus Change-in-Domestic-Credit $(\boldsymbol{\Delta D})$. Domestic Credit froze up as banks stopped lending because of their insolvency when Greece was unable to issue new sovereign bonds in 2010. The central bank reserves did not increase; instead, the economy stopped. The Change-in-Money-Supply was controlled by the European Union provision of Euro dollars. Change in bank reserves $(\Delta \mathbf{R})$ was dependent upon capital flight from Greek banks to Swiss banks; and Change-in-Domestic-Credit $(\boldsymbol{\Delta D})$ was dependent upon solvency of Greek banks. The empirical reality about Reserves $(\mathbf{R})$ of Euro dollars was quite different from Polak's assumption.

Criticism of the IMF's use of the Polak model has been made earlier by several economists. Joseph Stiglitz had criticized IMF austerity policy: "The IMF combined the money with conditions... higher interest rates... cutbacks in government spending and increases in taxes. The IMF would claim that imposing these conditions was the responsible thing to do...The IMF programs, with all of their conditions and with all of their money, failed... As a crisis progressed, unemployment soared, GDP plummeted, banks closed... The crisis economies... were clearly threatened with a major downturn and needed stimulation. The IMF programs pushed exactly the opposite course... Today, the IMF admits that the fiscal policy it recommended was excessively austere [7]."

Ngaire Woods also wrote: "In defining its craft, the IMF is heavily constrained both by its capacity and by the limits put upon it by its most powerful members. Within these constraints for a long time, the Polak model (and successive financial programming models) made life relatively easy for the Fund... That said, financial programming was severely challenged during the 1980s as the IMF sought an appropriate response to the debt crises that afflicted so many developing countries... The downside of professionalism for the IMF (and the World Bank) is that there is very little room for local knowledge. Local knowledge is messy, political, intractable, and very difficult to make judgments about [5]." This meant that micro-economic information was not properly used to modify macro-economic models. As a macro-economic model, the Polak four equations were used by IMF policy to justify austerity. Reducing government expenditure could force people into the private sector, thereby lowering wages for reducing cost-of-production (raising productivity) and increasing exports by lower prices of manufactured goods.

In this paper, we are not criticizing the IMF generally but only demonstrating that the Polak model (if the IMF was still using it to justify austerity policy) was not empirically true in the case of Greece. Austerity policy focuses both upon raising taxes and reducing government employment, immediately and at the same time"front-loading" government cuts to stimulate the economy.

The Polak macro-economic model assumed a direct connection (1) between imports and GDP and (2) between export-import difference and central bank monetary reserves minus next capital inflows. Why these assumptions? And if the Polak model were empirically accurate, then one might expect IMF policy based upon it to effective. But the policy was ineffective in Greece; and any model, underpinning the austerity policy, was invalid. (Earlier, one of the authors analyzed the IMF Polak model when it was applied by IMF austerity policy to the Argentine fiscal crisis in 2000; and the empirical evidence was that the model had also been invalid in the 
case of Argentina [8].)

Yet Polak was an able economist. Why did Polak make these assumptions? Why has the assumptions (about exports-imports and the productivity-of-labor) as the major factors in economic stability continued to influence so much economic thinking? The authors can only suppose that the economic idea connecting labor-costs-andexports traces back to traditional economics in the early history of the industrial revolution. Karl Polyani had traced the history of ideas in economic thinking in 1800s [9]. At that time, economic thinking had focused upon exports, because what industrial technology was doing was producing too-much-product-to-be-consumed-locally.

Then English economic thinking had focused upon exports and imports. More exports were good! More imports were bad. A positive difference of exports to imports created prosperity and wealth in England. A negative difference created economic recession in England. Economic recession was bad, because capitalists lost wealth and labor lost employment. What could management do to increase exports and decrease imports? The economic thinking then was to increase unemployment-as a way to reduce labor prices thus reducing production costs and thus decreasing export products' prices-thereby increasing exports and profits. This was a solution. Management can control employment. Firing labor increased exports by reducing prices. When exports increased, labor could be rehired.

Looking back historically, labor cost had been a major factor in production. In the 1800s, manufacturing automation was not yet a technology and would occur only later in the 1900s. In the 1800s, manufacturing needed many people to run the machines, as industrial labor. In the time of the English industrial revolution, labor had been a large part of production costs - roughly 50\% of production costs was in labor and $50 \%$ in materials. (Then the costs-of-production did not include the cost of factory investment, because manufacturing machinery was directly purchased and not financed by loans.) Accordingly, while material costs could not be controlled by English capital, labor costs could be controlled by increasing unemployment and making people more willing to work at lower wages.

But in the modern twenty-first century, labor costs in most manufacturing are no longer large costs. Computerization and automation has taken most of the labor costs out of manufacturing. Labor costs are now around only $5 \%$ of direct production costs; while material costs are still high, around $35 \%$ and overhead is the remainder of the $60 \%$ of direct costs. (The exception to this is the cost of labor in clothing assembly, as labor costs are still at least 35\%, with material costs 35\% and overhead 30\%.) The difference in manufacturing costs between the nineteenth and twenty-first century has been in the technologies of manufacturing automation. Automation progressed rapidly all through the twentieth century. For this reason economic thinking about an industrialized economy in the 1800s is not appropriate for modern economic thinking about present industrialization. The Polak model constituted economic thinking by IMF officials, which was 100 years out of date about technology.

Yet in 2011, European Union macro-economic policy advisors were still assuming that it was the "high-price" of labor which reduces "competitiveness" in an economy and that the price of labor can be reduced through unemployment. Government employees are assumed not to be productive to the economy. Fire government employees, and they will be forced to find lower-paying-but-productive employment in the private economy. This was the thinking in the earlier quoted EU Commission report. Apparently, historical technological progress in 'automation' was ignored in EU macro-economic thinking.

Sometimes models are used which are convenient to policy. About the IMF Polak model, Ngaire Woods wrote: "The Polak model offered staff a way to diagnose and prescribe conditions for any economy facing a balance of payments crisis... The original model required few data. It focused attention on a key variable that governments could control—domestic credit creation [5].” In the four years of the EU austerity policy, there had been no public expression of an underlying macro-economic model. However, IMF had long used the Polak model to underpin its austerity policies; and if the Polak model had lain behind the austerity policy, one could test its validity in the Greek context.

On empirically validating macro-economic models, sometimes econometrics is methodologically appropriate and sometimes institutional analysis is appropriate. Econometrics provides correlations between factors, which may be included in a model. A model depicts the empirical correlations as kinds of variables whose relations can be tested. Econometric analysis was not as appropriate a methodology for testing the Polak model, as were the methodologies of institutional and microeconomic analysis. The validity of the kinds of variables in the Polak macroeconomic model depended on the situation of the microeconomics of Greece, its institutional infrastructure. The microeconomics was that Greece was not a major manufacturing export nation and only had principle 
industries in shipping and tourism. Also as a member of the EU monetary union, Greece had no control over a national currency exchange rate and could not use central bank interest rates to deflate or stimulate the Greek economy. The macro-economic assumptions in Polak's model were not meet by the micro-economic situation in Greece.

\section{Disequilibrium Theory and a Dynamic Model of Greek Euro Crisis}

We turn now to a different macro-economic model of a national fiscal system-a model based "price disequilibrium" theory. In an earlier paper, one of the authors had analyzed how "disequilibrium pricing" occurred in the Greek sovereign bond market, using a systems dynamics modeling approach [10].

In 2009 the dynamics of the Greek fiscal crisis began when bond markets downgraded of the quality of Greek sovereign bonds. Bill Koenig reported: "Fitch Ratings said it downgraded Greece’s long-term foreign currency and local currency issuer default ratings to A- from A. The outlook is negative [11].” Next international markets responded negatively to the downgrade. Helena Smith and Ashley Seager reported: "Financial markets around the world sold off, after Greece's credit rating was cut, amid mounting concerns about its fiscal health. European stock markets tumbled and the Euro weakened sharply with investors becoming increasingly worried about dragging debt problems worldwide... The Fitch rating agency cut Greece's long-term debt to BBB+ from A minus. It marked the first time in 10 years that the country has seen its rating pushed below an A grade [12].”

Price-disequilibrium theory describes how financial market prices can, over time, deviate from a price equilibrium, due to leverage in speculation on capital-assets. In 2010, Greece's bonds went into "price-disequilibrium" when the "interest rate" on new issues of Greek bonds accelerated, Figure 1.

The discontinuous "jump" in interest rates on Greek Sovereign bonds began in 2010, when rates rose from $3.47 \%$ in January to $9.73 \%$ in July. This is what Paul McCulley called a "Minsky moment"-a time when market speculators realize a recent rapid price rise is a financial bubble and that market collapses [13]. Bond traders' confidence failed about the Greek government's capability to solve its fiscal problem. As bonds must return both interest on the loan and principle at maturity, suddenly, the market feared default. The market for new Greek bonds collapsed, as traders demanded higher and higher interest rates on new bonds.

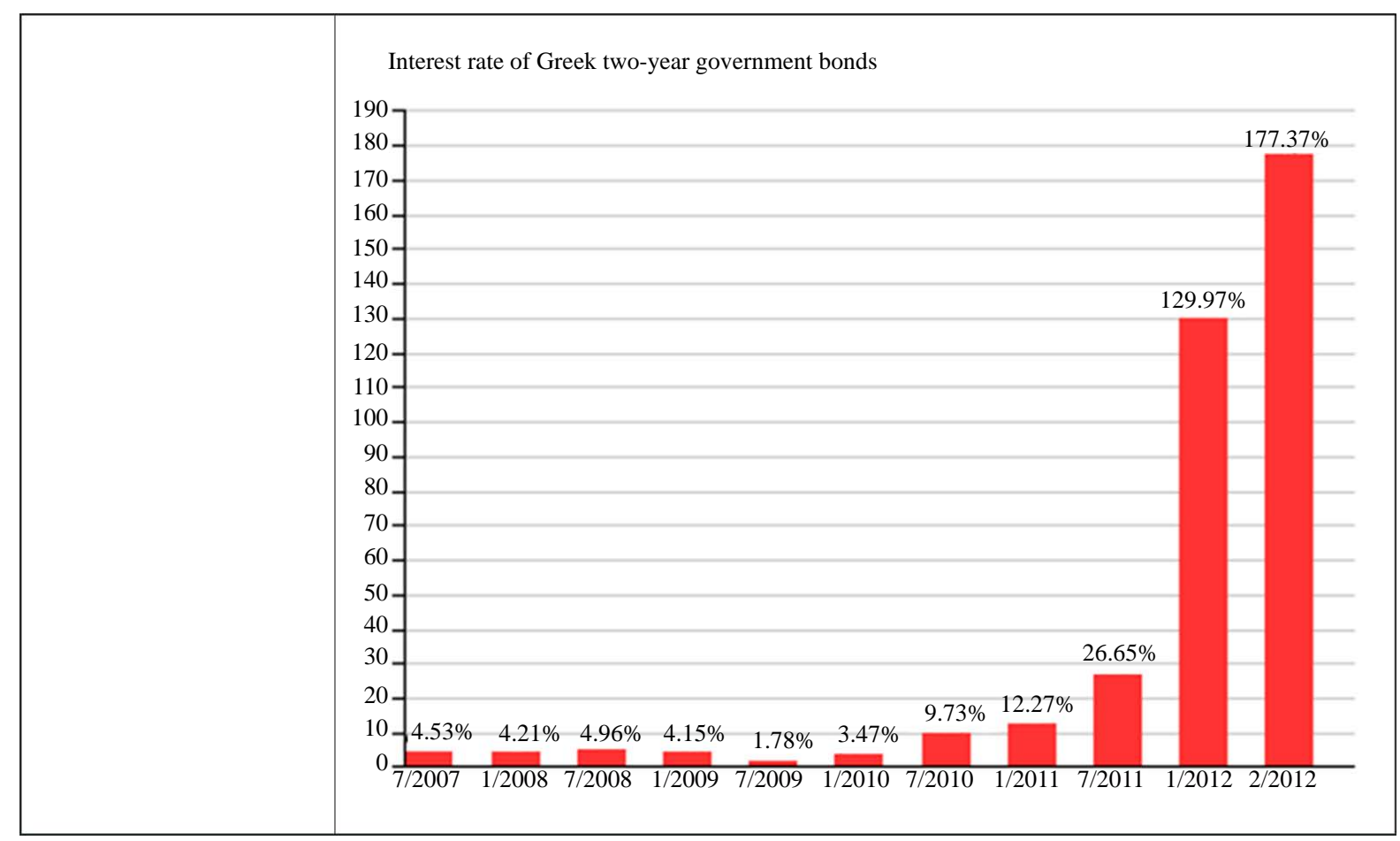

Source: (http://en.wikipedia.org/wiki/Greek_government-debt_crisis)

Figure 1. Interest rate of Greek two-year government bonds traded in the secondary market reflecting the markets' assessment of investment risk (source: Bloomberg). 
This kind of market anticipation is what George Soros has called 'reflexivity' in a financial market [14]. Anticipating a possible government default, traders would not buy new Greek sovereign bonds, except at very high interest rates. In 2011, the interest rate on Greek bonds jumped from $12.27 \%$ in January to $26.65 \%$ in August.

Long ago, John Maynard Keynes [15] and (later) Irvin Minsky [16] had argued that financial markets differ from commodity markets-because of the dimension of "time" in financial markets. In a commodity market, prices can reach an equilibrium between supply and demand, as commodities have only a single, immediate value of consumption by a consumer. However, in a financial market, capital assets have two values, an immediate value of rents and a future value of liquidity. This requires financial markets to be modeled with a time dimension. One can construct a price-disequilibrium model from the price-equilibrium model by adding the dimension of time [17]. In a three-dimensional market model, one can display the Greek bond "financial bubble" in the "rapid rise of interest rates" on a price-disequilibrium model, Figure 2.

One sees that the time chart of Greek bond interest rates fits empirically upon the Price-Time plane of the three-dimensional financial market disequilibrium model.

This price-disequilibrium model shows the result of a financial market when prices change discontinuously in time; but it does not show how a financial market can get into a disequilibrium. It does not show the dynamics (change over time) of the market. As next shown in Figure 3, one can model the dynamics of the Greek sovereign bond market [10].

National debt can be indicated as a kind of "stock" in systems dynamics notation. When tax revenue is insufficient to fund a government budget, then the "stock" of national debt will accumulate. This occurs when a government finances its budget deficits through issuing sovereign bonds.

Tax policy provides a feed-back loop to alter the budget deficit, as increased taxes lowers the deficit and decreased taxes increases the debt-for a given budget. The reflexivity of a bond market also acts as feed-back loop, as trader perception of the quality (riskiness) of the bonds affects the interest rate at which a market is willing to purchase a bond. As shown in the Figure 3, the Greek bond interest rates rose dramatically after 2009, when market confidence (reflexivity) declined over the soundness of Greek government policy, about its fiscal responsibility. The level of "interest rate" did operate as a kind of "control valve" on the "flow" of sovereign bonds into the "stock" of national debt.

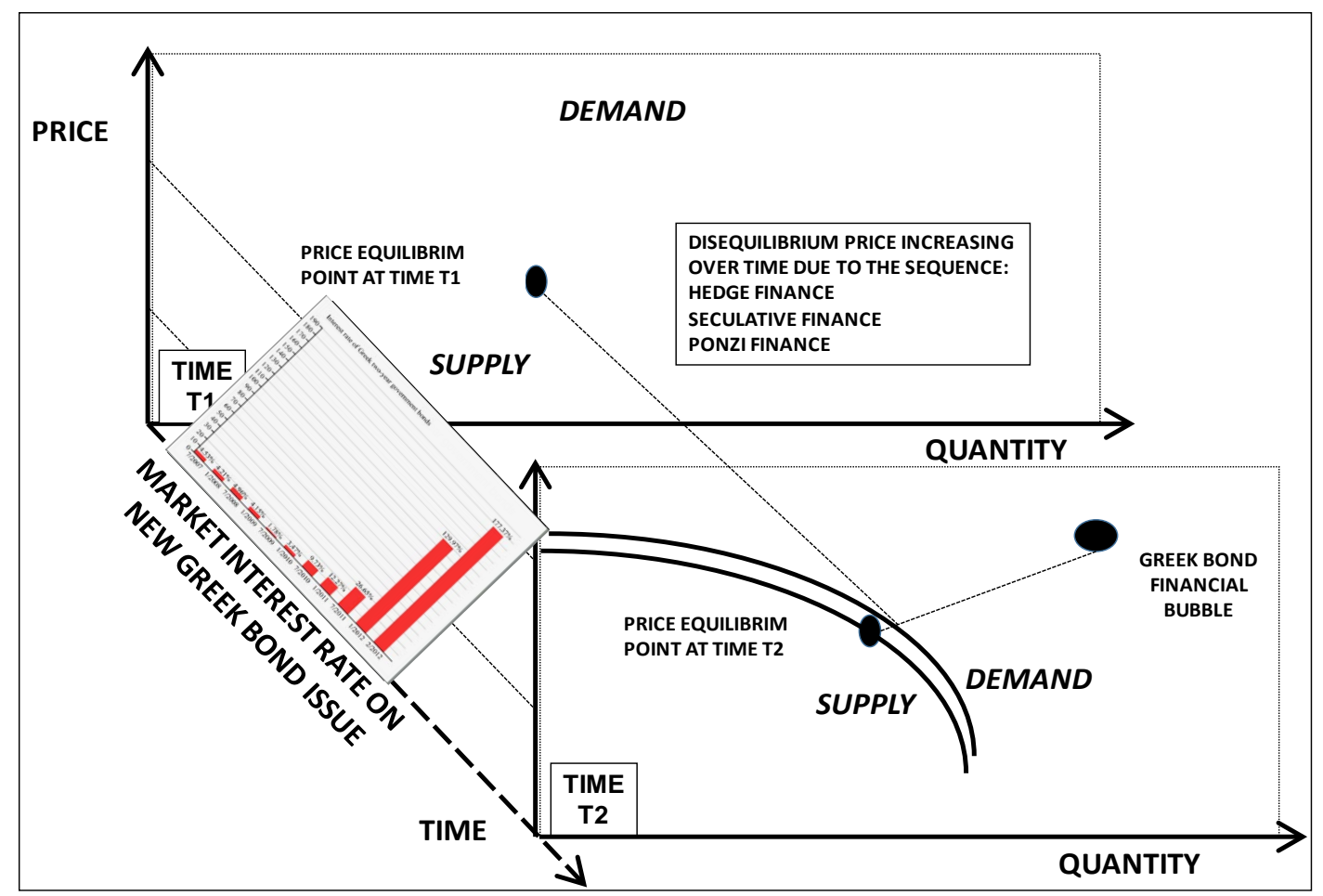

Source: Betz [10]

Figure 2. Greek sovereign bond interest rate as a price-disequilibrium chart. 


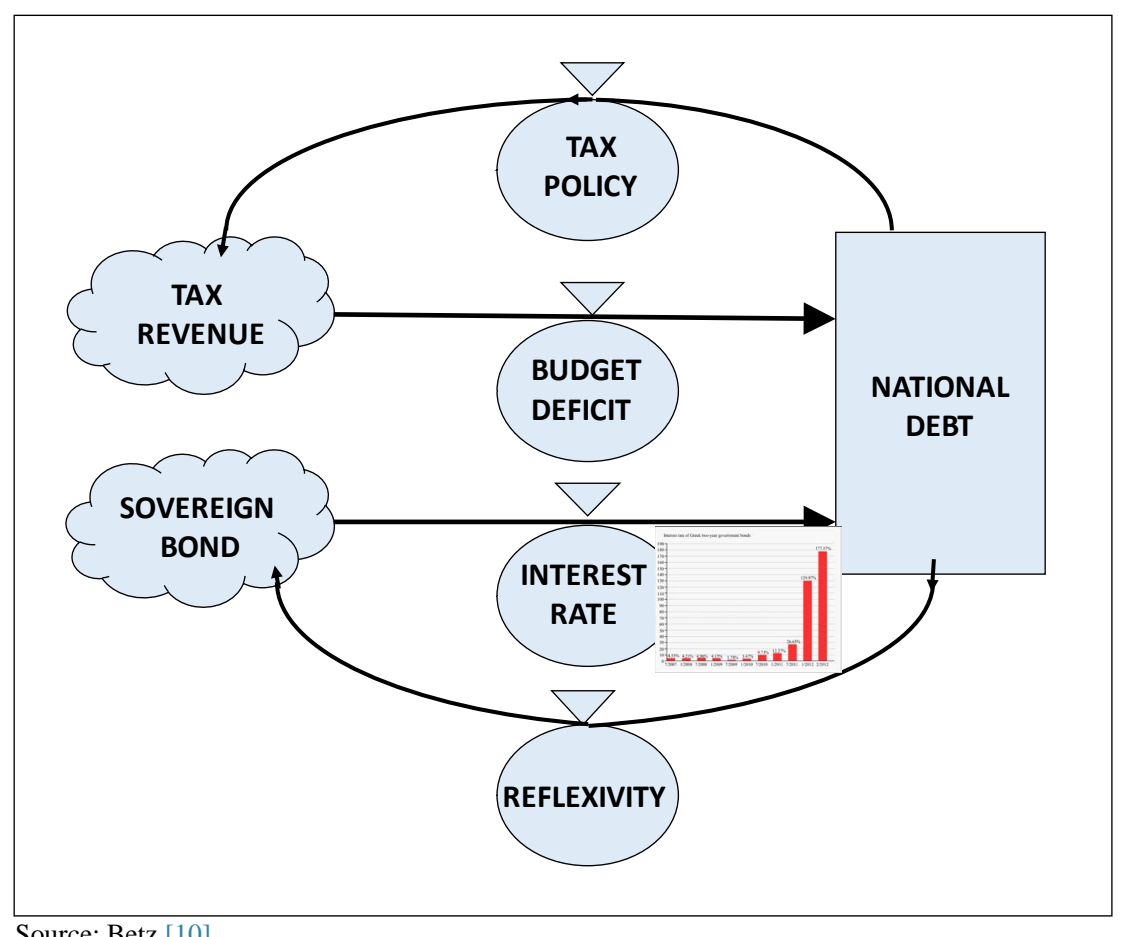

Source: Betz [10]

Figure 3. System analysis of EU dollar crisis in Greece 2010.

Adding all the relevant information available about the Greek fiscal policy into this systems dynamics model, one can obtain the model in Figure 4 [10]. As the national government debt continued to soar due to budget deficits from insufficient collection of taxes, the sovereign bond markets lost faith in the Greek government's continuing ability to service its debt.

Loss of confidence in government fiscal policy led to the collapse of Greek governments (and their replacements through new elections). Next to the tax revenue and sovereign bond sources, one can place a map indicating "government instability" in Europe, as a result of that Euro crisis. Many governments changed under the Euro crisis beginning in 2010; and some of these sought EU bailouts. The ratio of national debt to GDP in Greece was greater than any other nation in Europe.

Soros's concept of "reflexivity" in the behavior of the bond market (feed-back loop from National Debt Stock to Sovereign Bond Market) had been triggered by new information about Greece's fiscal policy. Martin Wolf wrote: "The moment of truth for the Eurozone came in October 2009, when George Papandreou, the incoming Socialist prime minister of Greece, told the world—and, above all, his country's long-suffering Eurozone partners-that its budget deficit for that year would be 10 per cent of GDP. This was well above the 6 to 8 per cent of GDP predicted only weeks earlier by the outgoing Conservative government. It was still more dramatically above the draft target for 2009 reported by the European Commission in June 2008, which was for a deficit of only 1.8 per cent of GDP (although that did include 0.75 percentage points in one-off deficit-reducing measures). In response, Jean-Claude Juncker, chairman of the finance ministers of the then sixteen-nation Eurozone group, said: 'The game is over. We need serious statistics.' In the end, the deficit reached 15.6 per cent of GDP [18].”

By July 2010, sovereign bond traders had connected information about the budget deficit to information about Greek tax policy. Then the market reflexivity about reliability of Greek bond jumped rates to $9.7 \%$. Martin Wolf wrote: "What made the Greek fiscal position so bad was not that its spending was extraordinarily high by Eurozone standards, but rather that its revenue was so low, given the country's high spending... It was the gulf between the Greek embrace of high public spending (much of it relatively wasteful) and the country's inability or unwillingness to raise taxes that lay at the root of its fiscal difficulties. This was ultimately a political failure more than an economic one, though a failure that membership of the Eurozone helped [18].”

As a macro-economic fiscal model in the Greek fiscal crisis, a price-disequilibrium systems dynamics model highlights "tax policy" as the key to solving the fiscal policy. 


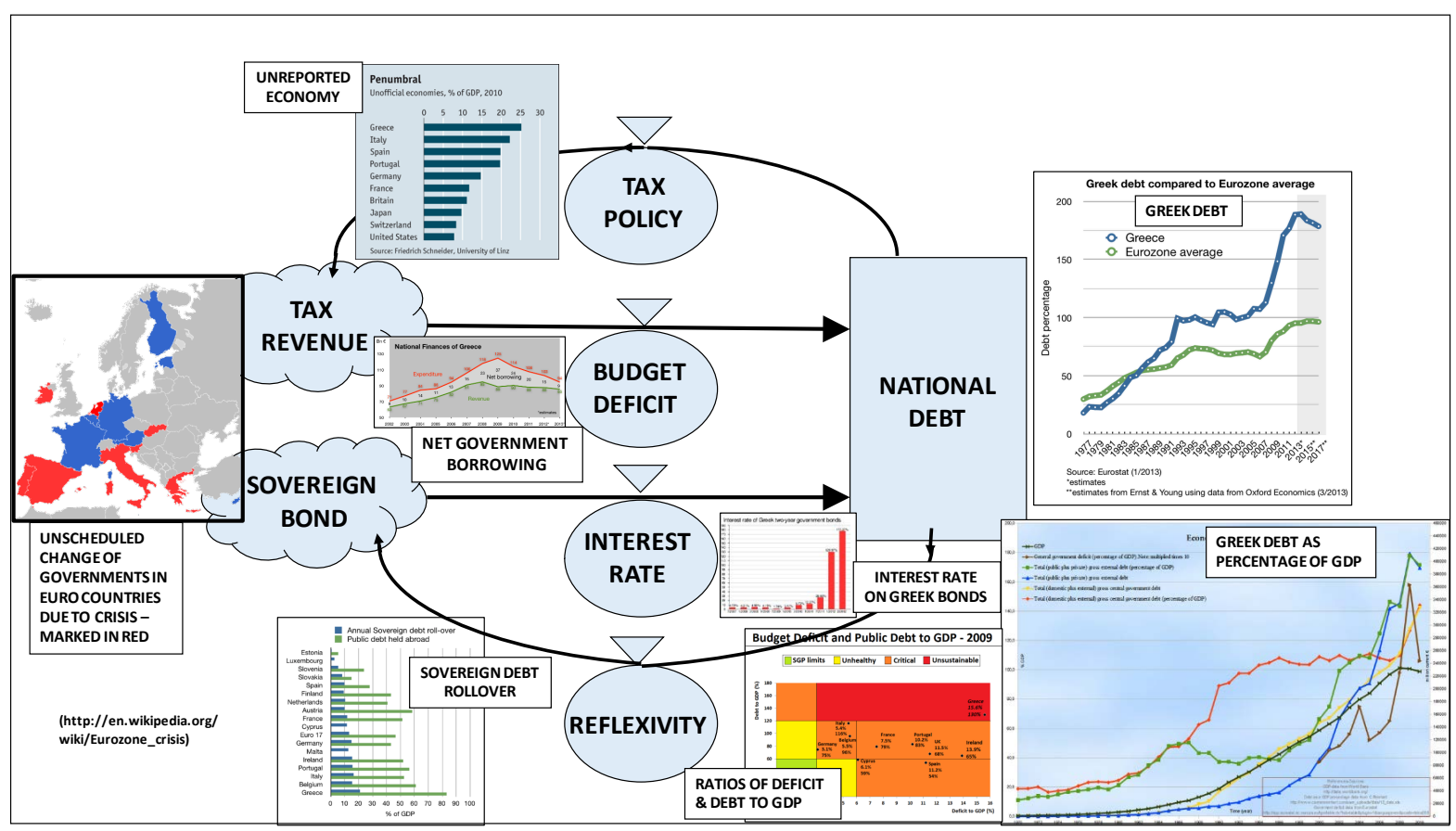

Source: Betz [10] and Charts from (http://en.wikipedia.org/wiki/Eurozone_crisis)

Figure 4. EU dollar crisis-Greece 2010 system analysis.

Only when sufficient taxes are collected to fund annual government budgets can government debt stop increasing.

There is no way out of the macro-fiscal-policy trap (continually-accumulating-debt funded by annual-issuesof-sovereign-bonds) except by collecting sufficient taxes to fund essential governmental operations.

A systems model depicts the types of relations in a phenomenon, such as "sources", "stocks", "feed-back loops", "control rates", etc. The systems dynamics technique indicates functional relations between charts of temporal economic data. It is in the functional relations that the model clearly points out that the major factor in the Greek fiscal crisis was poor taxation policy. The systems model is not just a display of charts and data but also how these charts of information relate to one another as system components, such as sources, flows, stocks, feedback loops, etc. The difference between information displays and models are the relationships between information (system variables).

\section{Austerity and Tax Policy}

Although tax reform was called for in the EU austerity program and also high-lighted in the disequilibrium fiscal systems model, yet little progress was made by the Greek governments. Tax evasion and government corruption were not substantially addressed, as Phillip Inman reported: "Primary Greek tax evaders are the professional classes. Greece is riddled with corruption, but a study shows that banks, politicians and professional workers are largely to blame... There is a political dimension that is centre stage at the moment, following proposals for closer union and control from Brussels and, in Greece's case, by the International Monetary Fund (IMF). Yet these economists ignore the challenges that beset a nation where very few people pay their taxes, where public-sector jobs are secured through family ties and where contracts for work, public or private, are rarely signed without someone in a position of power asking for a backhander. Greek banks are at the centre of the problem, as in Italy and Spain, where bankers perpetuate all the worst corrupt practices [19].”

Inman was basing his reporting partly upon a study of bank records by Artavanis Nikolaos, Adair Morse, and Margarita Tsoutsoura, who had gained access to records of one of the large banks in Greece. From that data, Nikolaos, Morese, and Tsoutsoura estimated the level of unreported tax bases of professionals in Greece: "We begin with the new observation that banks lend to tax-evading individuals based on the bank's perception of true income... We use household micro-data from a large bank in Greece and replicate bank models of credit capaci- 
ty, credit card limits, and mortgage payments to infer the bank's estimate of individuals' true income. From this, we estimated a lower bound of 28 billion Euros of unreported income for Greece. This foregone government revenues amounted to 31 percent of the deficit for 2009. Primary tax evading occupations are doctors, engineers, private tutors, accountants, financial service agents, and lawyers [20].”

Also from this study, the Economist reported: "Nikolaos, Morse, and Tsoutsoura found that, when professionals approached the bank for a loan or mortgage, their tax returns showed their debts almost exceeded their incomes (debt payments ate up 82\% of their incomes). For the beleaguered tax authority, this meant their income was too low to qualify for income tax. On average, they found the true income of self-employed people to be 1.92 times their reported income... (About) €28 bn (£22.4 bn) of tax was evaded in 2009 by self-employed people alone. As GDP that year was €235bn and the total tax base was just €98bn, it is clear that this was a significant sum. At a tax rate of $40 \%$, it amounted to almost half the country's budget deficit in 2008 , and $31 \%$ in 2009 [21].” This sample was from one bank's records. But it indicated the scale of the problem of "not-collected tax revenue". Professionals had reported only about half their income; and that un-reported income could have contributed to (fix) about one-half of the Greek annual budget deficit.

Another indication of the lack of government emphasis on tax policy occurred in 2012 when a Greek journalist dared to make public a list of tax evaders in Greece and was arrested. Mark Lowen reported: "Journalist Costas Vaxevanis has gone on trial in Athens for breach of privacy after publishing the names of 2000 Greeks with Swiss bank accounts. French authorities gave the names to their Greek counterparts two years ago, but documents were never investigated. Mr. Vaxevanis told the BBC that politicians should be prosecuted for keeping the names secret. But Greek officials have said there is no proof that those on the list have broken the law. Mr. Vaxevanis, 46, published the list in Hot Doc, the weekly magazine he edits. He is accused of breaking private data rules and faces up to two years in prison if convicted... Some of those named in the list, said to include many prominent Greeks, are suspected of using the HSBC accounts in Switzerland for tax evasion [22]."

Later the journalist Vaxevanis was acquitted of the charge, and the BBC News reported: "There was applause inside the court building as Mr. Vaxevanis was acquitted... The list of suspected evaders was reportedly leaked by an employee at the HSBC bank and passed to IMF chief Christine Lagarde when she was French finance minister in 2010. Ms. Lagarde apparently handed the list to the Greek authorities, but they took no action. Two of Greece's former finance ministers have acknowledged seeing copies of the list. However, Yannis Stournaras, who took office in June, has told parliament he has not seen it. Mr. Vaxevanis said he had published the list because it was his job as a journalist to reveal the truth. 'The three last governments have lied and have made a mockery of the Greek people with this list,' he said [23].” When EU officials passed on tax information to the Greek government officials, the information was ignored by the failure to emphasize tax reform.

Thus even in 2012, the EU Troika had been aware of the corruption in Greek tax policy but still funded the bailout of Greece. The Greek government deficit continued, even under severe cuts in public spending. By 2013, there was still a government deficit of 9 billion Euros (the difference between the budget of 94 billion and the tax revenues of 85 billion). The "feed-back-loop" of tax policy is the critical loop for sound government policy versus unsound government fiscal policy. If over time, tax revenues cannot support needed government services, then the financial system of a nation will be unstable in the long run.

\section{Results}

We have focused upon the net exports (exports minus imports) because there was an explicit austerity policy model constructed on this balance. There was a similar macro-balance in the minds of many economists as relevant to the Euro-dollar fiscal crisis. This was the current-account balances in the EU countries. For example about current-account balances, Martin Wolf wrote: "Indeed, the single most important lesson of the crisis is that the balance of payments continues to matter just as much within a currency union as outside one... Once a country inside a currency union becomes dependent on large net capital inflows, a sudden turnaround in these flows will cause an economic crisis. Such a crisis will be marked by a financial shock, as external funding is withdrawn, and a deep recession, as the imports on which the economy had come to rely can no longer be financed [24]." This again describes the economic result of a "front-loaded" austerity policy, as earlier emphasized by Roubini [1].

A current account balance of a nation is earnings on foreign investments minus payments made to foreign investors. In 2007, the current-account-balances-as-percentages-of GDP of the crisis EU nations were negative 
(with Greece a negative $14.4 \%$, Portugal a negative $10.1 \%$, and Spain a negative $10.0 \%$ ). In contrast, the EU nations not in crisis had positive balances (with Germany with a positive 7.5\%, Netherlands positive 6.7\%, Finland positive $4.3 \%$, Austria positive $4.1 \%$, Belgium positive $1.6 \%$, and the close-to-crisis France had a small negative balance of $1.0 \%$ ) [24].

Some economists have focused upon current-account-balances as a primary explanation of the Euro-Dollar crisis. Martin Wolf is an example, and he wrote: "These huge current-account surpluses and deficits can be viewed in three mutually consistent ways. First, they reflected private-sector capital flows towards what were mistakenly believed to be higher-return opportunities in more dynamic economies, such as construction in Spain... The second way in which the current-account deficits and surpluses can be viewed is as an excess of income over spending — or a surplus of savings over investment—in surplus countries and the opposite in deficit countries... Because they are jointly determined, it is logically impossible to say that countries in deficit are responsible for their plight while those in surplus are guiltless... The third way is that the surpluses and deficits reflected strengthening external competitiveness in surplus countries and declining competitiveness in deficit countries. Real unit labor costs in the former group of countries, especially in Germany, stagnated and real unit labor costs in the latter soared from the beginning of the Euro [24].”

Competitiveness is one of the main reasons why current-account balances are seen as decisive factors in a financial crisis. Although Martin Wolf did not approve of the EU austerity policy, yet competitiveness was (the third way, "productivity”) was still prominent in Wolf's explanation of the crisis. Wolf assumed that labor costs are an important factor in economic competitiveness; but as we earlier noted, because of automation, labor cost in modern manufacturing is not significant for productivity. In a manufacturing firm, labor cost more impacts "profits" than "competitiveness". This does not mean that nations need not be economically competitive. They do need to be competitive; but also they need to have a government which "lives within national means". Year after year after year, governments should not use foreign borrowing to pay for current services, covering over continuous budget deficits. Tax policy is an important factor for national fiscal policy and needs first to be attended. But in the macro-economic explanations of EU economists, the high-cost of labor had been focused upon again and again—assuming high wages causes low productivity.

Particularly when in a time of fiscal crisis, unemployment by itself cannot create a positive current-accountbalance, as unemployment may not only lower prices but also reduces demand. Reduction in aggregate demand by unemployment is recognized by economists; as for example, Martin Wolf also wrote: "A clash... arises within this low-inflation Eurozone, between improving competitiveness and managing the debt overhang. This is because a rapid restoration in competitiveness of countries like Italy or Spain requires falling wages and prices. But falling wages and prices also raise the real burden of debt. The relatively high interest rates on both private and public debt that characterize these economies make the problem of managing debt even harder. This is 'debt deflation' - a condition in which debtors are forced to save an ever higher share of their incomes in order to pay down debt, because the latter's real value is rising over time [24]." Certainly, it is difficult for labor to save "an ever higher share of their incomes in order to pay down debt" when they have no income as unemployed workers. A share of "zero" is still zero. But Martin Wolf, an outstanding financial reporter, knows this; as all economists know that any share of zero is still zero. Thus why the continual economic references to "productivity" as an explanation for the Euro-crisis in Greece? This has been particularly striking, since the principle reason for the Greek negative current-account-balance was not due to "productivity” but to government "profligacy" (continuous unbalanced government budgets, even in good economic times, funded by sovereign bond issues).

Perhaps, the fiscal policy focus on productivity has occurred because the variables of "employment”, "competiveness”, "productivity” (while important aspects of macro-fiscal policy) have seldom appeared in fiscal models (such as the Polak model). And this kind of fiscal policy issue still needs to be addressed. Who benefits from and who pays for a fiscal austerity policy? As an example of economists who do emphasize employment, Paul Krugman discussed this: "So is the 'austerian' impulse all a matter of psychology? No, there's also a fair bit of self-interest involved. As many observers have noted, the turn away from fiscal and monetary stimulus can be interpreted, if you like, as giving creditors priority over workers. Inflation and low interest rates are bad for creditors even if they promote job creation; slashing government deficits in the face of mass unemployment may deepen a depression, but it increases the certainty of bondholders that they'll be repaid in full. I don't think someone like Trichet was consciously, cynically serving class interests at the expense of overall welfare; but it certainly didn't hurt that his sense of economic morality dovetailed so perfectly with the priorities of creditors. It's also worth noting that while economic policy since the financial crisis looks like a dismal failure by most 
measures, it hasn't been so bad for the wealthy. Profits have recovered strongly even as unprecedented longterm unemployment persists; stock indices on both sides of the Atlantic have rebounded to pre-crisis highs even as median income languishes. It might be too much to say that those in the top one percent actually benefit from a continuing depression, but they certainly aren't feeling much pain, and that probably has something to do with policymakers' willingness to stay the austerity course [2]." Although in 2011, European banks holding Greek bonds did have to take a "hair cut", a 50\% loss in the value of the bonds. Yet from 2011 to 2015, the result of debt was transfer the holding of Greek debt from private banks to Troika banking.

Here are two kinds of public and private interests, of which any policy formulated upon a macro-economic model needs to be aware. One "private interest" is that of "creditors" (bondholders), and another other "private interest" is that of "labor" (Greek employment). If the EU Troika identified the "public interest" of the European Union as those of the "creditors", then EU austerity policy was in the public interest of the EU. If, on the other side, the public interest of Greece lay in the private interest of Greek labor (employment), then EU austerity was not in the public interest of Greece. In the application of social science to policy, different private-public interests arise. (One notes that the economic measure of "employment" did not appear in Polak's macro-economic model.) EU Troika policy appears to have focused more upon creditors benefit as the EU "public good" than upon the Greek nation's employment as a "public good". This implies that macro-economic models need to have explicit in their models the factors of "employment" and "fiscal responsibility".

\section{Conclusions}

This research highlights the deficiency of an economic model which might have been used in justifying macro-economic fiscal policies of the European Union in dealing with the Greek Fiscal Crisis. The Polak model was a model focused on macro-exchange-rate policy. The disequilibrium-systems model is focused on macro-fiscal policy. The fiscal crisis in Greece was not one of monetary-exchange-rate but one of fiscal policies. The disequilibrium-systems model is more empirically-valid for the Greek Euro-dollar crisis. The two different models underpin different economic policies. The Polak model led to an austerity policy which did not immediately solve the fiscal problem but only deepened the Greek fiscal crisis into unemployment, recession, and government instability. An empirically-invalid economic model can influence bad economic policy, which can intensify and not solve an economic crisis.

What kind of economic policy might have a disequilibrium-systems model suggested for fiscal policy? In the case of the Greek Euro Crisis, tax policy is more important than export-import measures for contributing to national financial stability. (But tax policy had not been sufficiently emphasized in the EU austerity program.) Therefore, there could have been an alternate policy to "austerity" which would have emphasized making "tax reform" the immediate focus - before cutting government employment and privatizing government services. A solution to the Greek fiscal crisis might (1) lie in immediate tax reform and anti-corruption measures, but (2) place debt repayment into the future, and also (3) incur no new fiscal indebtedness, even from the IMF. The solving of the problem of the enormous debt (of prior Greek governments) could have been "kicked-downthe-road". Instead of loaning more money to Greece (increasing the national debt), the EU might better have paid (subsidized) the interest-service on Greek debt, while also forbidding the Greek government to incur new debt from the bond market—even from the EU Central Bank, the World Bank and the IMF.

In fact, the opposite was occurring. The IMF loaned money to Greece and then insisted that Greece pays it back, even while the Greek crisis continued. In April 2015, Greece and the EU Troika were still haggling over continuing the bailout, as the BBC News reported: "Greece has ordered its public sector bodies to hand over any reserve cash to help it meet a payment due to the International Monetary Fund (IMF). The country is running out of cash and must repay the IMF nearly $€ 1$ bn in May... Negotiators are trying to strike a deal ahead of a meeting of Eurozone finance ministers on Friday (24 April 2015). There are mounting fears that Greece could default on its debts and exit the Eurozone. Prime Minister Alexis Tsipras urgently needs money to pay government salaries as well as the country's debt repayments... [24]" In May 2015, government continued to pay back IMF loans, while still teetering on bankruptcy.

So the EU policy was the opposite of what might have repaired the Greek fiscal situation. While structural reform was going on in Greece, the EU did not help Greece service its debt and still loaned more money to Greece- deepening a spiral of national debt, which can be impossible to climb out. In contrast, a policy suggested by a disequilibrium-systems model would suggest differently-reform now and pay back debt laterwhen the reforms begin to work. 
Of course, Greece would have to cut government spending, but not immediately-if the EU had extended all debt over more time, paying the interest on the Greek debt, until it could be "restructured" and paid at a future debt. More immediate for Greece to begin to emerge from the fiscal crisis is the need for a complete overhaul of Greek government tax policy and an anti-corruption campaign. This could have gotten the budget into a current balance-as long as Greece did not have to, at the same time, service its enormous international debt.

A valid macro-fiscal model can suggest practical remedies to a fiscal crisis—and even help prevent such occurrence.

As historical events unfold, case studies made in real-time can be a continuing story. In April 2015, James Kanter summarized key events in the crisis to that date:

“Timeline: Greek Debt Crisis

- December 2009 Credit ratings agencies downgrade Greece on fears that it could default on its debt.

- May 2010 Europe and Greece reach a \$146 billion rescue package, conditional on austerity measures. Some economists say the required cuts could kill the patient.

- October 2011 Banks agree to take a 50 percent loss on the face value of their Greek debt.

- July 2012 Stocks soar after the head of the E.C.B. says policy makers will do 'whatever it takes' to save the Eurozone.

- January 2015 Greek voters choose an anti-austerity party. Alexis Tsipras becomes prime minister.

- February 2015 European leaders hashed out a deal to extend the bailout by four months, with caveats [25].”

James Mackenzie, Renee Maltezou, and George Georgiopoulos reported on the continuing controversy between the Greek government and the EU: “Greece's new leftist government opened talks on its bailout with European partners on Friday (January 30, 2015) by flatly refusing to extend the programme or to cooperate with the international inspectors overseeing it. Prime Minister Alexis Tsipras' government also sacked the heads of the state privatization agency after halting a series of state asset sales. The politically unpopular policy of privatization to help cut debt is one of the conditions of Greece's 240-billion-euro bailout that has imposed years of harsh austerity on Greece [26].”

On 23 April 2015, there had been a meeting between leaders of Germany and Greece to reach a political agreement for releasing additional EU funding. Renee Maltezou, George Georgiopoulos, and Foo Yun Chee reported: "The German Chancellor Angela Merkel said on Thursday (24 April 2015) everything must be done to prevent Greece running out of money before it reaches a cash-for-reform deal with its international creditors amid heightened concern that Athens is nearing the brink. Merkel, Europe's pre-eminent leader, was speaking after a meeting she called 'constructive' with Greek Prime Minister Alexis Tsipras on the sidelines of a European Union summit in Brussels.... Their talks came a day before Eurozone finance ministers meet in Riga to review progress — or the lack of it-in slow-moving negotiations between Athens and the creditors... A Greek official said of the Merkel talks... there was 'convergence' that Greece would aim for a primary budget surplus_-before debt service_-of 1.2 to 1.5 percent of gross domestic product this year. That is far below the goals of 3 percent in 2015 and 4.5 percent in 2016 set in Greece’s 2012 EU/IMF bailout programme [27].” In April 2015, the Greek government was requesting an additional 7 billion Euro loan, intending to repay an IMF loan of 1.7 billion due in May. On 14 May 2014, Greece was still borrowing more money from the IMF to pay back the IMF. The Korea Herald reported: "Greece admitted Tuesday (May 12) it tapped into an emergency account in IMF to pay 750 million Euros due to the IMF... Billions more in loan repayments are due over the next three months... Experts say Greece is required to replenish the 600 million Euros that it withdrew from the emergency account as soon possible [28].”

Under the austerity program, the firing of Greek government employees and reduction of government services had reduced the budget deficit (before debt service) to a "budget surplus". This indicates that the reforms in the Greek government budget could pay for government operations, yet still not service debt. This is evidence that an alternative policy could have aimed at a budget-balancing-program in Greece-subsidizing debt service without adding new debt. And such an alternative policy would have been indicated by a disequilibrium dynamics model of Greek macro-fiscal policy. Yet the Troika policy was still to loan Greece more money, increasing Greece's debt load. Giving a country more debt when its basic problem is too much debt is not a practical solution.

\section{References}

[1] Roubini, N. (2014) Fiscal Policy. In: Akerlof, G.A., Blanchard, O.J., Romer; D. and Stiglitz, J.E., Eds., What Have We 
Learned? International Monetary Fund and Massachusetts Institute of Technology.

[2] Krugman, P. (2013) How the Case for Austerity Has Crumbled. The New York Review of Books. http://www.nybooks.com/articles/archives/2013/jun/06/how-case-austerity-has-crumbled/

[3] Blyth, M. (2013) The Austerity Delusion: Why a Bad Idea Won Over the West. Foreign Affairs. http://www.foreignaffairs.com/articles/139105/mark-blyth/the-austerity-delusion

[4] EU Brussels (2011) Conclusions of the Heads of State or Government of the Euro Area. European Union. http://www.consilium.europa.eu/uedocs/cms_data/docs/pressdata/en/ec/119809.pdf

[5] Woods, N. (2006) The Globalizers: The IMF, the World Bank, and Their Borrowers. Cornell University Press, New York.

[6] Polak, J.J. (1989) Financial Policies and Development. Organization for Economic Co-Operation and Development. Polak, J.J. (1998) The IMF Monetary Model at 40. In: Economic Modeling, Vol. 15, Elsevier Science, Amsterdam, 395-410. http://dx.doi.org/10.1016/s0264-9993(98)00019-4

Polak, J.J. (2005) Economic Theory and Financial Policy. In: Boughton. J.M., Ed., International Monetary Fund, M. E. Sharpe, London.

[7] Stiglitz, J.E. (2002) Globalization and Its Discontents. W. W. Norton and Company, New York.

[8] Betz, F. (2013) Macro and Micro-Economic Policies in Financial Crises: Argentina 2000 and South Korea 1998. Business and Management Research, 2, 41-55. http://dx.doi.org/10.5430/bmr.v2n4p41

[9] Polyani, K. (1944) The Great Transformation. Beacon Press, Boston.

[10] Betz, F. (2014) Disequilibrium Pricing-Greek Euro Crisis. Theoretical Economics Letters, 4, 897-909. http://dx.doi.org/10.4236/tel.2014.49113

[11] Koenig, B. (2009) Fitch Downgrades Greece to A-From A. Bloomberg. http://www.bloomberg.com/apps/news?pid=munievents\&sid=a6Y6T3olWgX0

[12] Smith, H. and Seager, A. (2009) Financial Markets Tumble after Fitch Downgrades Greece’s Credit Rating. The Guardian, December 9. http://www.theguardian.com/world/2009/dec/08/greece-credit-rating-lowest-eurozone

[13] McCulley, P. (2007) Teton Remarks. http://web.archive.org/web/20091124124300/http://www.pimco.com/LeftNav/Featured+Market+Commentary/FF/200 7/GCBF+August-+September+2007.htm

[14] Soros, G. (1988) The Alchemy of Finance. Simon \& Schuster, New York.

[15] Keynes, J.M. (1936) The General Theory of Employment, Interest, and Money. Harcourt Brace, New York.

[16] Minsky, H.P. (1975) John Maynard Keynes. Columbia University Press, New York.

[17] Betz, F. (2014) Disequilibrium Pricing Theory. Theoretical Economics Letters. Scirp.org. February. http://www.scirp.org/journal/tel

[18] Wolf, M. (2014) The Shifts and the Shocks: What We’ve Learned—And Have Still to Learn—From the Financial Crisis. Penguin Books Ltd., City of Westminster.

[19] Inman, P. (2012) Primary Greek Tax Evaders Are the Professional Classes. The Guardian, Sunday, 9 September 2012. http://www.theguardian.com/world/2012/sep/09/greece-tax-evasion-professional-classes?CMP=twt gu

[20] Artavanis, N.T., Morse, A. and Tsoutsoura, M. (2010) Tax Evasion across Industries: Soft Credit Evidence from Greece. Chicago Booth Paper No. 12-25, University of Chicago Booth School of Business. http://ssrn.com/abstract=2109500

[21] Economist (2010) Southern Europe Will Have Trouble Increasing Its Tax Take. The Economist, Aug 12 th 2010. http://www.economist.com/node/16792848

[22] Lowen, M. (2012) Greek Journalist Costas Vaxevanis on Trial Over Bank List. BBC NEWS, 1 November 2012. http://www.bbc.com/news/world-europe-20163430

[23] BBC NEWS (2012) Greek Bank List Editor Costas Vaxevanis Acquitted. BBC NEWS, 1 November 2012. http://www.bbc.com/news/world-europe-20172516

[24] BBC NEWS (2015) Greece Debt Deal Reforms Will Combat Tax Evasion. BBC NEWS, 22 February 2015. http://www.bbc.com/news/business-31574868

[25] Kanter, J. (2015) Eurozone Ministers Admonish Greece for Slow Progress on Overhauls. New York Times. http://www.nytimes.com/2015/04/25/business/international/greece-euro-finance-ministers-meeting.html?_r=0

[26] Mackenzie, J., Maltezou, R. and Georgiopoulos, G. (2015) Greece Says Will Not Cooperate with 'Troika’ or Seek Aid Extension. REUTERS.

http://www.nytimes.com/reuters/2015/01/30/world/europe/30reuters-greece-politics.html 
[27] Maltezou, R., Georgiopoulos, G. and Chee, F.Y. (2015) Merkel—Must Prevent Greece Running out of Cash before Deal. REUTERS, New York Times.

http://www.nytimes.com/reuters/2015/04/23/business/23reuters-eurozone-greece.html

[28] Korean Herald (2015) Greece Raids Emergency Fund to Repay Debt. The Korean Herald.

http://www.koreaherald.com/search/?nt=1\&dt=2\&np=1\&hq=\&q=greece+raids+emergency+fund+to+repay+debt 